Kazakh - Russian International University,

Kazakhstan

\title{
SEgMENTATION OF COSMETIC SERVICES MARKET IN THE REPUBLIC OF KAZAKHSTAN
}

\begin{abstract}
In this article, the author considers market segmentation as a process of dividing the market into separate parts - segments that differ from each other with different sales opportunities of the manufacture's products. The author demonstrates such segment of the consumer market as the market of cosmetic services. Principle scheme of segmentation of the cosmetic services market is shown. Criteria and characteristics (principles) of segmentation necessary for forming market segment are singled out. The article also focuses on the sequence of creating a market segment. The author reveals two principal approaches to marketing segmentation used in world practice. The basic principles of segmentation of the consumer market are described. Distribution of income by population groups, \% in 2015-2017, is analyzed. (for April month), on the basis of which the possibility of breaking up potential consumers into stable segmental groups was considered, segmentation of the population on the basis of income can serve, when the entire population is divided into five $20 \%$ of groups. The author distinguishes and describes the characteristic features of the methodology, segmentation which consists of successive stages. The point of view of modern world marketing is to first see the market segments, and then the country. The issue is not so much about the market potential of Kazakhstan, but about the potential among all consumers of cosmetic services. The main companies now describe the segments of the world market and the niches that cross national borders. They can be achieved physically, using a variety of means of communication and distribution channels, but the psychological target orientation is realized similarly. These segments are identified on the basis of adherence to similar concepts of the ideal product. This allows the company to develop the same product range for such segments, and the product is sold to the same target segments for benefits in numerous countries.
\end{abstract}


Goal: Purpose of this article is to consider the cosmetic services market segmentation as one of the most important marketing tools. Also consider market segmentation as a process of dividing the market into separate parts - segments that differ from each other with different sales opportunities of the manufacturer's products. Identify such a segment of the consumer market as the market of cosmetic services. Analyze features of the distribution of income by population groups, $\%$ in $2015-2017$ (for the month of April), also to break down potential consumers into stable segmented groups based on income, when the entire population is broken down into five $20 \%$ of the groups, to consider enterprises segmentation by the size of trade turnover and areas of activity.

Methods: Methods of document analysis (translation of primary and especially secondary data into targeted information), analysis of methodological and educational literature, observation (the method of collecting primary marketing information about the studied, by monitoring selected groups, customers, employees of the enterprise) are used as methodological tools.

Results: In this article, market segmentation as a process of dividing the market into separate parts is considered - segments that differ from each other with different sales opportunities of the manufacturer's products. Also there considered such segment of the consumer market as the market of cosmetic services. Features of income distribution by population groups, $\%$ in 2015-2017, are analyzed (for the month of April), a breakdown of potential consumers into stable segmented groups based on income was also carried out, when the entire population is divided into five $20 \%$ of the groups, the segmentation of the enterprise according to the size of trade turnover and spheres of activity was considered.

KEYWORDS: marketing strategy, marketing complex, market, competitors, marketing, and advertising.

Segmentation of the market is the process of dividing the market into separate parts - segments that differ from each other with different sales opportunities of the manufacturer's products, i.e., this is the breakdown of the market into distinct groups of buyers, each of which may require separate products. Segmentation of the market is one of the most important marketing tools.

A market segment is a specially allocated part of the market, a group of consumers of products or enterprises that have certain common characteristics. Market segmentation can be carried out in different ways on a variety of criteria. The goal of market segmenting is to identify the most important commodity needs for each group of consumers and to orient 
their policies to meet demand (Rice E. Trout J., (2010) .Positioning: battle for recognition.) St. Petersburg: Peter, 275-278 p).

The success of the enterprise in the competitive struggle largely depends on how correctly the target of the market segment is chosen. When forming a market segment, the criteria and characteristics (principles) of segmentation are distinguished. Criterion is a yardstick of an estimation of validity of a choice of a market segment for the enterprise or its goods. A sign is an indicator of the allocation of this market segment. When forming a market segment, the following criteria can be used:

- differences between consumers, allowing them to be combined into a segment

- similarity between consumers, forming the stability of this group of consumers to the product

- availability of indicators that allow measuring the characteristics and requirements of consumers, determine the market capacity

- ability to withstand competition

- sufficiency of sales volume to ensure coverage of expenses and profit

- segment availability for the enterprise (availability of sales and transportation channels)

Market segment is created in the following sequence:

- analyzes customer requirements for the product of the firm

- groups of buyers with similar requirements for a certain product are formed

- The production of this product and the possibility of changing the technology, allowing to produce goods that meet the requirements of groups of buyers

- competitiveness of the goods is evaluated

- determine economic benefit of creating a market segment

- marketing program for the market segment is being developed (Rodin V.G., (2009), Fundamentals of Marketing. - M.: Case, 504-506 p.).

Segmentation is division of consumers into groups in accordance with a number of stable features called marketing "signs of segmentation". The 
need for segmentation is due to the need to choose the optimal segment for positioning the service on the market (Soloviev B.A., (2015.) Marketing. - M.: Infra-M, 383-391 p) In the process of segmentation, segments of the consumer market are being formed, unifying characteristics and possessing a set of expressed characteristics for the successful positioning of services. General scheme of segment analysis is presented in Table 1.

Table 1

Schematic diagram of segmentation process of the cosmetic services market

\begin{tabular}{|c|c|}
\hline $\begin{array}{c}\text { Selecting the Segmentation Method } \\
\text { "a priory” }\end{array}$ & "posthoc (cluster - based” \\
\hline $\begin{array}{c}\text { Consumer market: choice of social and de- } \\
\text { mographic features of segmentation. }\end{array}$ & Method of „K-segmentation” \\
\hline $\begin{array}{c}\text { Industrial market: "full census” or the choice } \\
\text { of financial description feature. }\end{array}$ & \\
\hline Criterial evaluation of the segment. & \\
\hline
\end{tabular}

In the world practice, two principal approaches to marketing segmentation are used. In the first method, called "a priory", there are preliminary known signs of segmentation, the number of segments, their number, characteristics, and a map of interests. That is, it is implied that the segment groups in this method have already been formed. The "a priory" method is often used in cases where segmentation is not part of the current research, but serves as an auxiliary basis for other marketing tasks. Sometimes this method is used with very clear certainty of market segments, when the variability of market segments is not high. "A priory" is also acceptable for the formation of a new service focused on a well-known market segment (Akulich, I.L. (2015).) Fundamentals of Marketing 2nd ed., Rev. - Moscow: Higher School, 236-240 p).

Segmentation is by the "a priory" method.

To describe segmentation using "a priory" method, first of all, it is necessary to determine the type of market on which the service is supposed to be positioned. There are two types of markets, according to the type of 
services provided (Calendzhyan, S.O. (2016).) How to draw up a plan for marketing a trading company: M.: Case, $80-85$ p).

Consumer market is individuals or households that buy goods and services for personal final consumption. The services, mainly sold in the consumer market, include: household services, apartment repair services, etc.

Consider basic principles of consumer market segmenting. When segmenting the consumer market of services, geographic (regional consumer groups), psychographic (personality type, social environment, temperament, etc.), motivational (intensity of consumption, purchase purpose, etc.) and demographic (age, gender and so on) are usually used etc) signs of segmentation. That is, having a socio-demographic "cut" of the society, obtained, for example, based on the results of the population census, it is possible to single out and adopt a number of consumer segments for positioning (Lubanova T.P. (2015.) Meet Marketing! / Rostov / D: RO VOIVT, 170-176 p)

When choosing the number of segments to which the consumer market should be divided, they are usually guided by the objective function - determining the most promising segment.

Table 2

Distribution of income by population groups, \% in 2015-2017 (for April month)

\begin{tabular}{|c|c|c|c|c|}
\hline № & Name of population group & April 2015 & April 2014 & April 2017 \\
\hline 1 & "Low" & 10.60 & 6.80 & 7.80 \\
\hline 2 & "lower average" & 15.30 & 11.60 & 12.70 \\
\hline 3 & "middle" & 19.20 & 16.40 & 17.30 \\
\hline 4 & "high" & 23.80 & 23.20 & 24.40 \\
\hline 5 & "elite class" & 31.10 & 42.00 & 37.80 \\
\hline
\end{tabular}

For example, when segmenting by income level, it is recommended that all potential buyers be split into equal segments, taking into account that the volume of each segment was at least not less than the expected volume of services sold based on knowledge of the production capacities of the enterprise (Titova V. A., Tsoi ME, Mamonova EV (2015) - Marketing Management - Novosibirsk: NSTU Publishing House, - 484-488 pp.). 
Table 3

Segmentation of clients of a beauty salon on an age basis

\begin{tabular}{|c|c|l|}
\hline № & Segment & \multicolumn{1}{c|}{ Segment Specifications } \\
\hline 1 & Youth (16-22 years old) & Students, faces for the first time turned to beauty salons. \\
\hline 2 & $\begin{array}{c}\text { Young people who } \\
\text { recently formed a family } \\
\text { (25-30 years old) }\end{array}$ & $\begin{array}{l}\text { Persons wishing to be served in beauty parlours, but, } \\
\text { as a rule, limited in financial terms. }\end{array}$ \\
\hline 3 & $\begin{array}{c}\text { Families ,with experience" } \\
\text { (25-45 years) }\end{array}$ & $\begin{array}{l}\text { People with a developed career, but limited freedom } \\
\text { of financial action. The primary goals are to improve } \\
\text { housing conditions, provide financial protection for the } \\
\text { family, provide education for children. And only then care } \\
\text { for their appearance. }\end{array}$ \\
\hline 4 & $\begin{array}{c}\text { Faces of "mature age" } \\
\text { (40-55 years) }\end{array}$ & $\begin{array}{l}\text { People of this category have an increase in income as } \\
\text { financial liabilities decrease. They can afford regular visits } \\
\text { to beauty salons. }\end{array}$ \\
\hline 5 & $\begin{array}{c}\text { Persons preparing for } \\
\text { retirement (55 or more) })\end{array}$ & $\begin{array}{l}\text { People have accumulated capital and are trying to ensure } \\
\text { its safety. Beauty salons are not visited by many, mostly } \\
\text { women. }\end{array}$ \\
\hline
\end{tabular}

The presented distribution of income by five $20 \%$ of population groups is regularly given in statistical compendiums and summaries. Obviously, the convenience of working with such segment groups, especially in terms of tracking their capacity (Victor Jan V. (2013) Promotion: The Communication System between Entrepreneurs and the Market. - Kharkov: Humanitarian Center. 478-481).

In the description of consumers of the industrial market, when the number of enterprises-consumers that make up the segment is quite high and there is no possibility of forming a "complete census", segmentation is applied based on the characteristics associated with the activity of an industrial enterprise or its characteristics (Gilbert A. (2010) St. Petersburg: Peter, - 442-448 p.)

Obviously, signs of segmentation cannot be defined "a priory" without an appropriate study of consumers. But nevertheless, there is always the possibility to assume possible signs of segmentation. First, you can interview the sellers of the company directly selling sales to customers for possible ways of dividing consumers (Golubkov E.P. (2010) Marketing, Dictionary. 
- M.: Phoenix-480 p. Hershgen H. Marketing: the foundations of professional success: A Textbook for high schools. - Moscow: Delo, 2010. -418-421 p).

For example, when segmenting consumers of the "depilation" cosmetic service as perceived signs of segmentation, on the basis of which consumers can be divided into stable groups, the following were selected:

- "Age";

- "How often a client visits a beauty salon";

- "How often the client does hair removal in the salon";

- "Does the client use this kind of depilation, like laser hair removal".

Table 4

\section{Stage II. Carry OUt a SURvey}

Enterprises segmentation by the size of trade turnover and spheres of activity

\begin{tabular}{|c|c|l|}
\hline № & Firm sector & \multicolumn{1}{c|}{ Segment Specifications } \\
\hline 1 & Small firms & $\begin{array}{l}\text { Family enterprises with limited financial resources. Absence of an ad- } \\
\text { ministrative apparatus, a minimum of planning. The scope of activ- } \\
\text { ity is territorially limited. Commercial success is connected with the } \\
\text { policy of 1-2 key persons. Financial expertise is limited to the advice } \\
\text { of a bank or a certified accountant }\end{array}$ \\
\hline 2 & Services sector & $\begin{array}{l}\text { A large number of workers. The need for long-term funding sources } \\
\text { to expand operations }\end{array}$ \\
\hline 3 & Retail & $\begin{array}{l}\text { A large number of workers. A large amount of accounting and ac- } \\
\text { counting work, as well as cash transactions }\end{array}$ \\
\hline 4 & $\begin{array}{c}\text { Manufacturing } \\
\text { industry }\end{array}$ & \begin{tabular}{l} 
Problems of financing. Indoor demand \\
\hline
\end{tabular} \\
\hline 5 & $\begin{array}{c}\text { Services and } \\
\text { retail trade }\end{array}$ & $\begin{array}{l}\text { Orientation to expansion and seizure of markets. The presence of } \\
\text { a wide network of branches with extensive staff for implementation } \\
\text { and administrative control }\end{array}$ \\
\hline 6 & $\begin{array}{c}\text { Manufacturing } \\
\text { industry }\end{array}$ & $\begin{array}{l}\text { Great need for investment in buildings and equipment. The desire } \\
\text { to introduce new products, which gives rise to the need for scientific } \\
\text { research. The constant striving to conquer new markets, especially } \\
\text { beyond the border }\end{array}$ \\
\hline 7 & Agriculture & $\begin{array}{l}\text { High level of specialization of production. Seasonal cash problems. } \\
\text { Relatively low return on capital }\end{array}$ \\
\hline
\end{tabular}


At the second stage, a questionnaire is prepared and a survey is conducted. The goal of the survey is to assign each of the clients to certain differentiated items of the segmentation criteria selected in the second stage. This condition (the existence of differentiated items in each question) determines the need to form only closed questions (Khrutsky E., Korneeva I.V. (2011) Modern marketing: a benchmark book on market research. - M.: Infra-M, - 507-511p)

Only customers of the company who buy a product or service (or are on maintenance) are interrogated in the local time interval, preferably within 1 month.

So, on the basis of the expected signs of segmentation, we form a questionnaire.

1. Please indicate your age.
a) to 20 ;
б) 20-35;
в) $35-55$;
г) over 55

2. How often do you visit a beauty salon?
a) I do not visit;
б) 1 once a month;
B) twice a month;
г) Every week

3. How often do you do hair removal in a beauty salon?

\begin{tabular}{|c|c|c|c|}
\hline a) I do not visit; & 6) too seldom; & $\begin{array}{l}\text { в) spring } \\
\text { and summer; }\end{array}$ & г) Regularly \\
\hline
\end{tabular}

4. Do you use this method of depilation, like laser hair removal?

\begin{tabular}{|l|l|l|l|}
\hline $\begin{array}{l}\text { a) I do not know } \\
\text { what it is; }\end{array}$ & б) not used; & в) not like & $\begin{array}{l}\text { No, } \\
\text { I would not like }\end{array}$ \\
\hline
\end{tabular}

Stage III. There is definition of "suitable" features of segmentation. The degree of "fitness" of a certain feature of segmentation can be considered the presence of a certain mathematical correlation between a pair of alleged signs 
(the presence of a correlation between questions in this study). The presence of a high correlation level (the highest value of the calculated mathematical correlation coefficient) indicates the presence of the relationship between the features, that is, the possibility of their joint use. And it is possible to single out a stable segment group only at the intersection of two signs of segmentation. For this, the correlation coefficient between the questions (possible signs of segmentation) is computed in pairs (Eriashvili N.D., Howard Yu.A. (2014), etc. Marketing. - M.: Infra-M - 466-471p)

Stage IV. There is selection of segments. On the basis of the obtained features of segmentation, the segment groups (also called "consumer segments") can be formed. Logically, the segments should be 16 (in this example). But the use of such a number of segments is impossible. First, some segment groups will be too small (up to $5 \%$ of the total number of customers). Secondly, it is extremely difficult to differentiate the range of services in relation to such a large number of segment groups, and it is not rational in fact. Usually, 4-6 stable segmental groups are allocated, in relation to which product differentiation is made. Therefore, according to the table above, the percentage of respondents who are in one of the 16 groups of possible segment groups is calculated, assuming that this percentage can be extended to all clients. Groups with the highest percent are allocated as market segments.

Consider this, for example, the intersection of the signs of segmentation "how often the client visits the beauty salon" and "whether the client uses this type of hair removal, like laser hair removal” (Table 5).

Table 5

"Visiting beauty salon and using laser hair removal"

\begin{tabular}{|c|c|c|c|c|c|}
\hline № & $\begin{array}{c}\text { "Using laser hair } \\
\text { removal" }\end{array}$ & “attendance" & $\begin{array}{c}\text { Once } \\
\text { a month }\end{array}$ & $\begin{array}{c}\text { Twice } \\
\text { a month }\end{array}$ & Every week \\
\hline 1 & $\begin{array}{c}\text { I do not know what } \\
\text { it is }\end{array}$ & 1 & 2 & 3 & 4 \\
\hline 2 & No, I do not use & 5 & 6 & 7 & 8 \\
\hline 3 & I would like to try & 9 & 10 & 11 & 12 \\
\hline 4 & Yes, I'm using & 13 & 14 & 15 & 16 \\
\hline
\end{tabular}


Possible number of segments created at the intersection of the segmentation marks "how often the client visits the beauty salon" and "whether the client uses this type of depilation, such as laser hair removal"

Possible number of segments formed at the intersection of the signs of segmentation "how often the client visits the beauty salon" and "whether the client uses this kind of depilation, like laser hair removal".

There is critical assessment of perspective segments. The final stage of formation of segmental groups (regardless of the way in which segmentation was done) is the "criterial estimation" of the selected segments, within the framework of which their compliance with a number of marketing criteria for the success of positioning services on them is considered. (Abchuk V.A. (2013) The ABC of Marketing - SPb.: Peter - 396-403 p).

In assessing the criterion of the segment capacity, a positive parameter can be considered the opportunity to direct all the production capacities of our enterprise to work in this segment, i.e. The capacity of the segment should be greater than or equal to the production capacity of the service enterprise (Lukin A.V. (2016) Marketing .- Moscow: Forum - 224-226 p).

The criterion of segment availability for the enterprise: an analysis of this issue gives management information if it has the opportunity to start promoting its services in the selected segment, or else it is necessary to take care of the formation of the sales network and the establishment of relations with intermediaries. That is, the question is: did the company work with this segment before?

Criterion of segment materiality is an assessment of how this group of consumers is stable in its main unifying characteristics. Is this segment growing, stable or decreasing is it worth to orientate its production capacities (Matanov A.N. (2012) Efficiency of advertising. - M.: Finpress - 413-417 p.).

By the criterion of segment compatibility with the market of the main competitors, the management of the enterprise should receive an answer to the question of the extent to which the main competitors are ready to give up the selected segment of the market, how much advancement in this market affects their interests. And if the main competitors are seriously concerned about the promotion of services by our enterprise in the selected segment and take appropriate measures to protect it, then it is necessary to be prepared 
to incur additional costs when targeting this segment and take into account relevant measures when developing marketing tactics (Pankrukhin A.P. (2015) Marketing - M.: Omega-L, - 655-661 p)

If selected segment of the market satisfies the management of the enterprise by all criteria, then a decision is made to position the range of services provided in this market niche. For the successful positioning of our services on this segment, the level of competitiveness of our services should not be lower than that of competitors (Patten D. (2013) Successful marketing for small businesses. - M: Faire-Press, 368-372p.).

The question is how to build a marketing policy beauty salon. Some directors of salons do not always understand what marketing policy is and how it can help them in their work. So, in order: Marketing is the activity for studying, creating and fully satisfying both existing and future needs of clients, which as a result leads to an improvement in the relationship with your customers (Bernet J., Moriarty S. (2011) Marketing communications: an integrated approach.: Peter - 864-870 p.)

To do this, we give a well-known model of "forces that control competition" in the salon business. In addition to the factor of the appearance of new competitors taken into account by the leaders, it should be understood that the price policy of your enterprise is influenced by suppliers that force the cabin to set certain prices, and customers or customers that force you to reduce prices in the form of setting discounts and other price actions (Golubkov E. P. (2014) Fundamentals of Marketing: A Textbook. - Moscow: Case - 418-420 pp.).

Change in the marketing policy of the enterprise is facilitated by the appearance of products or substitute technologies. So, hair removal or figure correction can be carried out in accordance with various technologies, which affects the price of this service. As the influence of substitute products, one can consider the appearance of miostimulators of different levels and qualities on the market. The wide spread of cosmetology equipment produced in Southeast Asia leads to a fairly significant reduction in prices for this equipment, and as a result to a fall in prices for services. The introduction in those or other regions of more stringent administrative requirements for the opening beauty salons leads to an increase in investment costs and an 
increase in the payback period. The process of marketing planning of the salon activity should include consideration of the following points:

- needs and wishes of consumers of beauty salons;

- customer satisfaction after visiting the beauty industry;

- goods, services and strategies of competitors - direct and indirect - for this beauty salon;

- trends in the economic development of the salon business and the specific enterprise;

- social trends observed in the region;

- political regulation and lobbying of interests;

- features of the existing legislation relating to the salon business and its expected changes;

- technological discoveries in the field of salon business.

Estimation of the market and potential clients, their needs is made by the method of questioning, (Golubkova E.N. (2013) Marketing communications. - M.: Tandem - 279-283 p).

Only a clear understanding of why and when a customer needs to buy a name from your price list will help to successfully and sell a lot, rather than "to flog". It is rather difficult to achieve such a simple goal. Why? We will try to understand. Work and interaction with customers on the basis of accounting for their benefits allows you to quickly establish a strong relationship. Otherwise, it turns out "to flog", which often remains a single or rare sale. Remember how you treat active and persistent sellers (employees of the salon), working on you using psychological techniques, for example, neurolinguistic programming. So, the success of the salon depends on the effectiveness of customer satisfaction. Do not rely on the superiority of the goods; rely on meeting the needs of the market. 


\section{References:}

Abchuk V.A. (2013) The ABC of Marketing - St. Petersburg: Peter - 396-403 p.

Akulich, I.L. (2015). Basics of Marketing 2 ed., Rev. - Moscow: Higher School, 236-240 p.

Bernet J., Moriarty S. (2011) Marketing communications: an integrated approach. - SPb.: Peter - 864-870 p.

Burtsev V.V. (2012) Improving the system of sales management // St. Petersburg: 364 pp.

Calendzhyan, S.O. (2016). How to make a plan for marketing a trading company: Trans. from English. / Calendzhyan S.O. - M .: Case ,. - 80-85 p.

Eriashvili N.D, Howard Yu.A. (2014), etc. Marketing. - Moscow: Infra-M - 466-471 p Gilbert A. (2010) Marketing research - St. Petersburg: Peter, - 442-448 p.

Golubkov E.P. (2010) Marketing. Dictionary. - Moscow: Phoenix - 480 p. Hershgen $\mathrm{H}$. Marketing: the foundations of professional success: A textbook for high schools. - Moscow: Delo, 2010. - 418-421 p.

Golubkov, E.P. (2014) Fundamentals of Marketing: A Textbook. - Moscow: The Case - 418-420 p.

Golubkova E.N. (2013) Marketing communications. - Moscow: Tandem - 279-283 p. Khrutsky V.Ye., Korneeva I.V. (2011) Modern marketing: a handbook on market research. - Moscow: Infra-M, - 507-511 p.

Lukina A.V. (2016) Marketing. - Moscow: Forum - 224-226 p.

Lyubanova, T.P. (2015.) Meet the marketing! / - Rostov n / a: RO VOIVT, 170-176 p. Matantsev A.N. (2012) Effectiveness of advertising. - Moscow: Finpress - 413-417 p. Pankrukhin A.P. (2015) Marketing. - Moscow: Omega-L, - 655-661 p.

Patten D. (2013) Successful marketing for small businesses. - M.: Fair Press, - 368-372p. Rice E. TroutJ. , (2010). Positioning: the battle for recognition. SPb: Peter, 275-278 p. Rodin V.G., (2009). Fundamentals of marketing. - Moscow: Delo, 504-506 p.

Soloviev B.A., (2015). Marketing. - Moscow: Infra-M, 383-391 p.

Titova V.A., Tsoy M.E., Mamonova E.V. (2015). - Marketing management. - Novosibirsk: Publishing house of the NSTU, - 484-488 p.

Victor Jan V. (2013) Promotion: A system of communication between entrepreneurs and the market. - Kharkov: The humanitarian center. $-478-481$ p. 
